\title{
Lobbying in the EU Comitology System
}

Nørgaard, Rikke Wetendorff; Nedergaard, Peter; Blom-Hansen, Jens

Published in:

Journal of European Integration

DOI:

10.1080/07036337.2014.889128

Publication date:

2014

Document version

Early version, also known as pre-print

Citation for published version (APA):

Nørgaard, R. W., Nedergaard, P., \& Blom-Hansen, J. (2014). Lobbying in the EU Comitology System. Journal of European Integration, 36(5), 491-507. [4]. https://doi.org/10.1080/07036337.2014.889128 


\title{
Journal of European Integration \\ Journal of European Integration
}

\section{Lobbying in the EU Comitology System}

\author{
Rikke Wetendorff Nørgaard, Peter Nedergaard \& Jens Blom-Hansen
}

To cite this article: Rikke Wetendorff Nørgaard, Peter Nedergaard \& Jens Blom-Hansen (2014) Lobbying in the EU Comitology System, Journal of European Integration, 36:5, 491-507, DOI: 10.1080/07036337.2014.889128

To link to this article: https://doi.org/10.1080/07036337.2014.889128

曲 Published online: 14 Mar 2014.

Submit your article to this journal $\pi$

LII Article views: 1197

Q View related articles

View Crossmark data $\nearrow$

4 Citing articles: 6 View citing articles $\asymp$ 
ARTICLE

\title{
Lobbying in the EU Comitology System
}

\author{
RIKKE WETENDORFF NØRGAARD*, PETER \\ NEDERGAARD** \& JENS BLOM-HANSEN***
}

\author{
*Ministry of Business and Growth, Copenhagen, Denmark; \\ *Department of Political Science, University of Copenhagen, Copenhagen, Denmark; \\ **Department of Political Science and Government, University of Aarbus, Aarbus, \\ Denmark
}

\begin{abstract}
Comitology is an important part of the EU's regulatory framework. Hence, lobbying by outside interests is to be expected. However, lobbying in the comitology system has received almost no scholarly attention. This paper provides the first understanding of the subject by analysing the access of business interests to actors in the comitology system. The analysis is designed as a most likely study of two cases, aviation safety and $\mathrm{CO}_{2}$ quotas. Based on Bouwen's rationalist theory of access goods, the empirical analysis shows that lobbying is prevalent, especially by sectoral interests providing expert knowledge and targeted mainly at the Commission, but also at the member states in the comitology committees, and the European Parliament. The case studies therefore indicate that lobbying is widespread in the comitology system and important to study in order to understand the outputs from this part of the EU political system.
\end{abstract}

KEY WORDS: comitology, lobbyism, EU, rationality, Bouwen's 'access' theory

\section{Introduction}

Over the years, the EU's regulatory activity has grown so much that the Council of Ministers and the European Parliament increasingly delegate rule-making powers to the Commission. Today, the Commission is therefore an important rule-maker. In fact, most EU rules are now Commission

An earlier version of this article was presented at an internal seminar at the Department of Political Science, University of Copenhagen. We wish to thank Asmus Leth Olsen, Caroline Howard Grøn and three anonymous reviewers for valuable comments.

Correspondence Address: Peter Nedergaard, Department of Political Science, Copenhagen, Denmark. Email: pne@ifs.ku.dk 
rules. However, the Commission is no autonomous rule-maker. In most areas where it has been delegated powers to issue rules, oversight committees composed of representatives from member states (so-called comitology committees) monitor them.

The world of comitology committees remains one of the least illuminated aspects of the EU political system. Only in the last 10-15 years has scholarly interest developed, and today the history of the comitology system, its institutional set-up, its incidence and daily operation is no longer a white spot on the EU map (Bergström 2005; Blom-Hansen 2011; Brandsma 2010; Christiansen, Oettel, and Vaccari 2009). But one aspect remains understudied: lobbying by outside interests. From the general literature on lobbyism in the EU, we know that interest groups are about as active at the European level as they are within the member states (Coen 2007; Greenwood 2007; Kohler-Koch 1997; Mazey and Richardson 2006; Nedergaard 2009). However, their involvement and influence in the comitology system remain largely unstudied.

Observers of the comitology system have noted that interest groups pay considerable attention to it. For example, the Commission's own 2002 study of the system noted 'that third parties, interest groups, industry and NGOs are always trying to influence the work of committees, both with the Commission and in the Member States with the Member State governments. This is normal procedure ...' (Commission 2002, 219; Egan and Wolf 1999, 252-3; see also Schaefer and Türk 2007).

In addition, case studies of selected individual comitology committees, although undertaken for different purposes, often note that interest groups may be involved in the committees' work: for example, the advisory committee on safety, hygiene and health protection (Daemen and van Schendelen 1998), the standing committee on foodstuffs (Neyer 1998), the eco-label regulatory committee (Philip 1998), GMO-authorisations (Gatt 2009) and the committee on the wild birds' directive (Alfé, Brandsma and Christiansen 2009).

However, this amounts to scattered evidence. To the best of our knowledge, there is no systematic study of lobbying in the comitology system. In the general literature on comitology, the phenomenon is hardly even mentioned (Bergström 2005; Blom-Hansen 2011; Brandsma 2010).

The purpose of this paper is to provide a first understanding of lobbying by outside interests in the comitology system. We seek to uncover which interests are active and why, which EU institutions are targets of lobbying in the comitology process, and when and why interest groups gain access.

Given the limited scholarly attention paid to lobbying in the comitology process, we have designed our analysis as a most likely case study. The aim is to investigate whether lobbying in the comitology system merits more systematic study in the future by giving a first analysis of the characteristics of lobbying in this particular part of the EU system. Our study should thus be read as a plausibility probe (George and Bennett 2005, 75). Specifically, we have selected two cases - $\mathrm{CO}_{2}$ quotas and air traffic safety - which are technically complex, carry potentially important effects for private interests, and where the Commission is formally required to consult 
stakeholders. Furthermore, the cases have been selected because they provide outside interests with the maximum number of access points. Decisions on both cases are made under the regulatory procedure with scrutiny, which is the comitology procedure with the broadest involvement of EU institutions. Although this procedure was phased out after the comitology reform in 2011, it provides the most favourable opportunity for studying the extent to which lobbying in the comitology system is directed at the European Parliament. Finally, we not only study lobbyism at the EU level, but also at the member state level, which may provide outside interests with easier access to the member state representatives in the comitology committees. In the conclusion, we discuss in more detail what can be learnt from this most likely scenario.

Our study is limited in two senses. We only study business interests as represented by Business Interest Associations (BIA), and at the national level we only focus on one member state, Denmark. These limitations are due to practical reasons and are obvious points for further research to remedy.

The remaining part of the article is structured as follows: Section 2 introduces the comitology system. Section 3 presents the paper's theoretical framework, which is based on Bouwen's (2004) model of access to decision-making procedures. In Section 4 we discuss the selection of our two cases and other methodological issues. The empirical analysis, which finds lobbying to be pervasive, follows in Section 5. Finally, in the conclusion we discuss the wider lessons of our most likely case studies, inter alia in the light of the post-Lisbon comitology reform in 2011.

\section{The Comitology System}

The concept of 'comitology' refers to the process by which the Commission adopts implementing measures based on the authority delegated by the Council and the European Parliament. This is often done under the control of a comitology committee composed of experts representing the EU member states, normally officials from government ministries or agencies. The comitology committees are chaired by the Commission, which sets the agenda and distributes the meeting material, takes minutes, but does not have any voting rights (Brandsma and Blom-Hansen 2010; Commission 2002, 169).

Control of the Commission by comitology committees has a long history. It was introduced in the early 1960s, when the Common Agricultural Policy was implemented. However, it was not given any explicit Treaty foundation until the Single European Act in 1987. The Council then adopted its first comitology decision, which codified the various comitology procedures into four generic types (but with several variants): advisory, management, regulatory and safeguard. In 1999, the Council adopted its second comitology decision, which abolished the variants, but maintained the four generic types (Bergström 2005, 189-201; 249-78). In 2006, the second comitology decision was amended, and the regulatory procedure with scrutiny was added to the list. This gave the Council and the European Parliament veto rights, even after a positive committee opinion (Blom-Hansen 2011, 72-94). 
In 2009, the Lisbon Treaty introduced a distinction between delegated and implementing acts. While implementing acts are controlled by comitology procedures, delegated acts are controlled directly by the Council and the European Parliament (Christiansen and Dobbels 2013). Direct control will gradually replace the regulatory procedure with scrutiny in a process expected to be completed by 2014 (Hardacre and Kaeding 2011). In 2011, a new comitology regulation was adopted that changes the management and regulatory procedures into a new examination procedure (Brandsma and Blom-Hansen 2012; European Parliament and Council 2011).

In total, there are 250-300 comitology committees spanning all areas regulated by the EU (Commission 2010a). Accounts given before the Lisbon Treaty show that approximately two thirds of all Commission regulations, directives and decisions are adopted under comitology procedures (Brandsma 2010, 33). The post-Lisbon system both reduces and expands comitology control of the Commission. Direct Council and Parliament control of the new delegated acts reduces comitology and abolishes the regulatory procedure with scrutiny. But the 2011 reform expands comitology to include the common commercial policy (Brandsma and Blom-Hansen 2012). In sum, comitology continues to be a standard control mechanism in EU delegated decision-making.

While the composition of comitology committees does not differ across committees, the various comitology procedures specify the decision rule in the committees and the degree of involvement of the member states and the European Parliament. ${ }^{1}$ In particular, the position of the European Parliament varies considerably across procedures. In order to study the widest possible targeting of lobbying efforts, we focus on the comitology procedure, which provides the broadest involvement of the European Parliament. This is the regulatory procedure with scrutiny.

This procedure consists of two phases (Council of Ministers 2006, article 5a). In the first phase the Commission submits its draft measure to the relevant committee, which states its opinion by qualified majority. Prior to the vote, stakeholders are often consulted through open stakeholder meetings. ${ }^{2}$ In contrast to the other procedures, the draft measure is then in a second phase submitted to the Council and the European Parliament, irrespective of the committee's opinion. If the committee's opinion is positive, both the European Parliament and the Council can object to the draft, in which case the Commission must abandon it. If the committee gives a negative opinion or no opinion, the draft is submitted to the Council for decision and simultaneously sent to the Parliament for information. If the Council objects to the draft within two months, the Commission must abandon it. If the Council does not object, the Parliament then has four months to oppose the draft, in which case the Commission must abandon it.

In contrast to the other comitology procedures, the regulatory procedure with scrutiny thus provides the European Parliament with considerable influence. We expect this fact to make the Parliament an attractive target for lobbying in addition to the Commission and the comitology committees. Focusing on this specific procedure thus enables us to study the extent to which outside interests use all channels of influence. 


\section{Theoretical Expectations}

In the vast literature on lobbyism in the $\mathrm{EU}$, one of the fundamental issues remains how to study the influence of interest groups on policy outcomes (Dür 2008; Dür and De Bièvre 2007; Richardson 2007). One strand of studies has argued for the need to focus on the exchange of information for access to decision-makers (Bouwen 2004). Thus, from this perspective, lobbying is all about providing the right information to decision-makers (Chalmers 2011). Despite the obvious weaknesses of associating access with influence, it remains a fruitful path for studying lobbying, especially when it comes to the comitology system where decisions concern very complex parts of EU regulations. Therefore, this paper builds on Bouwen's (2004) access model, which is developed to explain lobbying by BIAs in the comitology system.

Bouwen (2004) argues that business lobbying may succeed because business organisations can provide the EU institutions with resources, so-called access goods. Three types of access goods are identified: expert knowledge, information about encompassing European interests and information about encompassing domestic interests (Bouwen 2004, 343). These goods, however, are not demanded by the various EU institutions to the same extent. Studying EU legislative politics, Bouwen argues that expert knowledge is primarily demanded by the Commission, information about European interests by the European Parliament and information about domestic interests by the Council. Since different types of business organisations can provide the access goods to various extents, Bouwen assumes that they are granted access to the various EU institutions to different degrees. For example, euro groups are expected to have access to the European Parliament, while domestic business groups are expected to have easy access to the member states in the Council.

To understand business lobbying in the comitology system, we adapt Bouwen's model in two respects. First, we introduce a distinction between general and sectoral business interests. As mentioned, Bouwen's model focuses on the legislative procedure where general and sectoral business interests can be expected to be equally influential (of course depending on the nature of proposed legislation). Bouwen therefore has little reason to distinguish between sectoral and general business interests. However, when studying lobbying in the comitology system with its high level of complexity and specificity, it can be useful to distinguish between sectoral and general business interests, because sectoral business interests can be expected to possess more of the specific expert knowledge needed in the comitology system.

Second, we need to re-think the demand side of Bouwen's model. The demand side in legislative decision-making is different from executive decision-making in the comitology system because the positions of the EU institutions differ. More specifically, we expect the Commission to demand expert knowledge since it is responsible for drafting implementation measures within the technical areas regulated in the comitology system. In addition, the Commission is, as guardian of the Treaty and the European common interest, expected to demand information about the encompassing 
Table 1. Overview of hypotheses

Access to Commission

$\mathrm{SEBI}>\mathrm{GEBI}>\mathrm{SNBI} / \mathrm{GNBI}$

Access to European Parliament

SEBI $>$ GEBI $>$ SNBI/GNBI

Access to member states in the comitology committees

$\mathrm{SNBI}>\mathrm{GNBI}>\mathrm{SEBI} / \mathrm{GEBI}$

Note: $\mathrm{SEBI}=$ sectoral European business interests; GEBI = general European business interests; $\mathrm{SNBI}=$ sectoral national business interests; $\mathrm{GNBI}=$ general national business interests.

A slash indicates that the rank order of access is theoretically indeterminate.

European interest. But again, due to the technical nature of comitology matters, we expect the Commission to first and foremost demand information of a sectoral nature.

Turning to the member states in the comitology committees, their representatives are typically experts from the national ministerial systems. Hence, we do not expect them to demand expert knowledge to the same extent as the Commission. Representing individual member states, they are more likely to demand information about domestic interests. Again, due to the technical nature of comitology matters, we expect their demand to have a sectoral, rather than general, focus.

Finally, we expect the European Parliament to demand expert knowledge in order to enable it to evaluate whether or not to oppose the Commission's measures. At the same time, and following Bouwen (2004), we expect the European Parliament to demand information about European interests, but again with a sectoral, rather than general, focus.

In sum, we end up hypothesising that business interests are granted access to all EU actors in the comitology system, but to varying degrees. Our hypotheses are summarised in Table 1.

\section{Research Design}

As mentioned in the introduction, very little attention has been paid to the study of lobbying in the comitology system. In order to gain a first insight into this, we have therefore based our selection of cases on a most likely design.

Our comparative analysis consists of two cases of rules adopted by the Commission under the regulatory procedure with scrutiny. In the first, hereafter referred to as the case of $\mathrm{CO}_{2}$ quotas, the Commission adopted a decision in 2011 on transitional union-wide rules for harmonised free allocation of emission allowances (Commission 2010b, 2011). This followed a 2008 decision by the EU's Heads of State and Government that, as part of the climate and energy package, the annual quantity of allowances in the EU's $\mathrm{CO}_{2}$ quota system should be set at the EU level from 2013. A portion of the allowances were to be allocated free of charge to companies in relation to so-called benchmarks; for example, the number of allowances per produced amount of paper, steel, etc. These benchmarks are calculated in the comitology system in relation to the $\mathrm{CO}_{2}$ emissions from the average of the 10 per cent most efficient producers in Europe (European Parliament and 
Council 2003, art. 10a). The comitology committee responsible for monitoring the Commission in the case of $\mathrm{CO}_{2}$ quotas was the Climate Change Committee chaired by DG Environment ${ }^{3}$ (Commission 2010b). The committee met approximately every second month between 2009 and 2011 to prepare and ultimately adopt the implementing decision (Informant K).

In the second case, hereafter referred to as the case of aviation safety, the Commission adopted a regulation on civil aviation security in 2009 (Commission 2009a, 2009b). This regulation includes the permission to screen persons and goods at airports. Not least the Commission's first proposal attracted much attention because it introduced body scanners as a method for screening individuals. The comitology committee responsible for monitoring the Commission in this case was the Committee for Civil Aviation Safety chaired by DG Transport ${ }^{4}$ (Commission 2009b). The committee met approximately 10 times in 2008-2009 to prepare and ultimately adopt the implementing regulation (Informant $\mathrm{H}$ ).

The data to analyse the two cases stems from interviews and documents, partly from the Commission's comitology register. Informants of business interests represent both general European and national general and sectoral organisations. Additional informants were selected representing the possible targets for the BIAs' lobbying activities: the Commission, the European Parliament and the comitology committees. A total of 11 informants were identified (please see Appendix for details), partly through examination of attendance lists and summaries of Commission stakeholder meetings, and partly through the snowball method, where informants were asked to identify other informants. All interviews were carried out in 2011.

Before conducting the analysis, it is necessary to translate our theoretical concepts into measurable variables. It is crucial to understand how access can be tested by the means of a qualitative inquiry. Bouwen (2004) conducted a large number of interviews with public officials in the Council, the Commission and the European Parliament to develop his theory of access goods. To obtain information about the relative access of lobbying actors, the officials were asked about their contacts with private interests.

In this study, we have followed the same idea by conducting a number of interviews with public officials asking them about their contacts with BIAs. Since the relatively small number of interviews (11) does not allow for statistical testing of the access, written sources such as the attendance lists of Commission stakeholder meetings have been added as an indicator of access. This empirical foundation evidently only allows for a limited investigation, which is why the analysis should be seen as a plausibility probe. The idea is to make a first attempt to point out the characteristics of lobbying in the comitology system.

\section{Empirical Analysis}

In this section, we investigate the hypotheses in three steps. First, we map the active BIAs in the two cases. Second, we investigate which EU institutions were targeted by their lobbying efforts. Third, we evaluate which BIAs were granted access to the comitology system. 


\subsection{Active Business Interests}

In accordance with our expectations, the European sectoral organisations seem to have been more active than the European general organisations in both the case of $\mathrm{CO}_{2}$ quotas and aviation safety. This is because the implementing measures adopted in both cases, and the associated costs, were targeted at a narrow range of business stakeholders, rather than at business interests in general.

In the case of $\mathrm{CO}_{2}$ quotas, it is clear from the attendance lists from the Commission's stakeholder meetings that the European sectoral organisations were strongly represented (Commission 2009c, 2009d). $\mathrm{CO}_{2}$ quotas carry significant costs, especially for energy-intensive industries, and because the basic act provides the same allocation to all producers of the same types of products throughout the EU (Ministry of Climate and Energy 2010, 1), a basis was created on which producers could meet in their respective sectoral organisations to maximise the number of free quotas for their particular products (Informant K).

One of the BIAs that was active in the case of $\mathrm{CO}_{2}$ quotas was Eurometaux, a European sectoral organisation representing the interests of the main EU and international metals producers and commodity groups, as well as national metal federations. For this organisation, the risk was that the metal industry would be excluded from the group of producers provided with free $\mathrm{CO}_{2}$ quotas. Consequently, it was strongly motivated to lobby. The new rules might therefore force small producers to close down and sharply curtail the production of others. Hence, there were vital interests at stake (Informant C).

In the case of aviation safety, two kinds of sectoral organisations were particularly active in dealing with the Commission's proposal: European airports (ACI Europe) and European airlines (Association of European Airlines - AEA). The risk that the airports would have to shoulder the costs of installing body scanners triggered ACI Europe to undertake lobbying activities. Smaller airports in particular would have difficulties in funding body scanners. At the same time, ACI Europe wanted major airports with the capacity to carry the financial costs to be able to voluntarily choose body scanners because this would allow them to meet pressure from the US government to intensify security screening of passengers travelling to the US (Informant G). The Commission's proposal also carried financial risks to the airline companies because the airports might collect taxes from the airline companies to fund the body scanners. In addition, the proposed body scanners jeopardised the airlines' recent mobility agenda. It was against this backdrop that the AEA also chose to launch lobbying activities (Informant J).

The national sectoral organisations were also active in the two cases. In the case of aviation safety, they initiated lobbying activities at the request of their European counterparts. ACI Europe thus made its members aware of the need to lobby and equipped them with information to contact the relevant national authorities. The division of labour between the European and national sectoral organisations in the case of aviation safety also reflects what in the literature is considered to be the very essence behind 
the membership of national sectoral organisations in European organisations. As pointed out by Greenwood $(2007,52)$, the majority of national economic and sectoral organisations justify such membership with access to information and 'advocacy', i.e. safeguarding their interests at European level in cases where they do not have the capacity to be active themselves.

In the case of $\mathrm{CO}_{2}$ quotas, the most active BIA at the national level in Denmark was the Confederation of Danish Industries. Somewhat surprisingly to us, this general business organisation lobbied on behalf of a single member, although this was part of a larger effort in which the member of both the national and the European sectoral organisation cooperated with the Confederation of Danish Industries to ensure that the benchmark for the member's product type was set 'correctly' on the basis of future $\mathrm{CO}_{2}$ quotas. The Confederation claimed that it was not able to assist all members in the same way as it helped this particular one, but that the lobbying effort was launched after a direct request from the member. The Confederation only assisted in this particular case because its efforts would not be at the expense of other members (Informant I and D).

The fact that a national general organisation such as the Confederation of Danish Industries engages in lobbying activities goes against our theoretical expectations. The same can be said for the European general organisation BUSINESSEUROPE's lobbying efforts in the case of $\mathrm{CO}_{2}$ quotas. This organisation is a broad and general European business group consisting of 41 national member organisations from 35 European countries, with members ranging from the energy sector to the chemical and financial sectors. Far from all members of BUSINESSEUROPE were concerned by the $\mathrm{CO}_{2}$ quotas, and those who were represented different sectors for which benchmarks for $\mathrm{CO}_{2}$ quotas could and should be set differently. Accordingly, it was an exercise in itself to ensure that no sectors were given first priority and special treatment. When BUSINESSEUROPE nevertheless chose to lobby in the $\mathrm{CO}_{2}$ quotas case, it did so on a cross-sectoral basis that involved the majority of its members. No priority was thus given to individual sectors and the individual gain for its members was estimated to be greater than the cost of engaging in lobbying activity in this particular field (Informant D).

\subsection{Targets for the Lobbying Activities of Business Interests}

The BIAs' choice of lobbying targets appears to be based on a rational assessment of which EU actors can best defend their interests. In the case of $\mathrm{CO}_{2}$ quotas, the European sectoral organisation, Eurometaux, first and foremost directed its lobbying at the Commission, as the Commission was responsible for drafting the proposal for an implementing measure, and hence needed to gather technical data that would ultimately determine whether or not Eurometaux' members would receive free $\mathrm{CO}_{2}$ quotas. Eurometaux expected that if it supplied the Commission with technical data, the Commission would be receptive to its messages and ensure that the process for the allocation of benchmarks with regard to $\mathrm{CO}_{2}$ quotas was carried out in a way that its members would be charged with the 
lowest possible cost (Informant C). The choice of one EU institution as a main target did, however, not preclude a parallel effort vis-à-vis another institution. Eurometaux also mobilised its national members and asked them to lobby their national representatives in the comitology committee, the Climate Change Committee. Eurometaux judged that the committee, due to its intergovernmental nature, would be receptive to the information which its national affiliates had to offer. Also, the European general organisation BUSINESSEUROPE encouraged its national member organisations in the case of $\mathrm{CO}_{2}$ quotas to contact their respective countries' representatives in the comitology committee, in addition to its lobbying efforts towards the Commission (Informant G).

In the case of aviation safety, the same reasoning was true for ACI Europe. The organisation worked to ensure that body scanners were made voluntary and not mandatory by focusing its lobbying efforts on both the Commission and the Committee on Civil Aviation Security. ACI Europe lobbied the Commission early on in the comitology procedure when the implementing measure was being drafted (by the Commission) and the impact assessment was being carried out to ensure that the implementing measure allowed for the use of body scanners. As soon as the Commission's draft implementing measure reached the Committee on Civil Aviation Security, ACI Europe asked its members to lobby the national members of the committee. ACI Europe thus targeted its lobbying efforts at the Commission and the comitology committee at the point in the comitology procedure where their respective powers were thought to be the greatest in order to maximise the potential for influence.

We also expected the European Parliament to be a desired target for the lobbying activity of BIA. However, in the case of $\mathrm{CO}_{2}$ quotas neither BUSINESSEUROPE nor Eurometaux actively lobbied the Parliament. Both organisations explained that they could not use it to change the Commission's draft because the Parliament's power to object to an implementing measure is a veto right rather than a right to make amendments. And they could not hope to persuade the Parliament to use their right of objection because it traditionally favours strict climate regulation, and an objection would mean the withdrawal of the Commission's draft and thus a return to the status quo with more lax regulation (Informant $\mathrm{C}$ and $\mathrm{D}$ ). Therefore, the organisations concentrated their lobbying activities elsewhere.

However, in the case of aviation safety, ACI Europe chose the European Parliament as a third target of lobbying in addition to the Commission and the comitology committee (Informant F). This may partly be explained by the fact that the Parliament's TRAN committee (responsible for the issue of aviation safety) may be more receptive to the lobbying efforts of BIAs than the ENVI committee (responsible for the case of $\mathrm{CO}_{2}$ quotas). The TRAN committee has, in contrast to the ENVI committee, appointed two special comitology rapporteurs in charge of handling all comitology cases. However, ACI Europe nevertheless directed its lobbying efforts against a broad group of members of the TRAN Committee. This was part of a general strategy, following the Parliament's increasing powers under the ordinary legislative procedure (Informant G). 


\subsection{Access to the Comitology Procedure}

In both the case of $\mathrm{CO}_{2}$ quotas and aviation safety, the basic acts require that the Commission consults relevant stakeholders, notably through open stakeholder meetings prior to the adoption of implementing measures (see e.g. Commission 2009c, 2009d). In addition to these general stakeholder meetings, more privileged bilateral contacts were made between BIAs on the one hand and the Commission, the comitology committees and the Parliament, on the other. As mentioned, the Commission demands mainly technical information on individual sectors, which is what in Bouwen's terminology is called 'expert knowledge' (Bouwen 2004, 340) and 'information about the European encompassing (sectoral) interest'.

In the case of $\mathrm{CO}_{2}$ quotas, Eurometaux was able to match the Commission's demand for information and thus gained access to it in the form of both the open stakeholder meetings and a series of bilateral meetings. Eurometaux could provide the figures and technical data from its member associations necessary to calculate the benchmarks for the metal sector and its subsectors. At the same time, Eurometaux was able, as a federation of national sectoral organisations, to provide information on how to implement the measure and how it would be received by the metal industry as a whole at the European level, i.e. 'information about the European encompassing (sectoral) interest' (Informant C). BUSINESSEUROPE was, as a European general organisation composed of national business associations, not able to provide detailed technical information or information about specific sectoral interests. Nonetheless, it had access to the comitology procedure in the form of one bilateral meeting with the Commission. However, meetings between the Commission and general business interests are only rarely about just one subject. The meeting in question between DG Climate and BUSINESSEUROPE thus included a range of matters in addition to the $\mathrm{CO}_{2}$ quotas (Informant D). In other words, access was probably derived from other cases, in which there may have been a better match between BUSINESSEUROPE's provision of access goods and the Commission's demand (Informant B).

The case of aviation safety showed exactly the same activities, structures and results. Here the European sectoral organisations, ACI Europe and AEA, were also able to provide the Commission with information, inter alia on the implications of body scanners in European airports and airlines. ACI Europe and AEA were able to provide the demanded information from their national members and frame it to a common European position (Informant B).

The comitology committees are composed of specialists in their own right, which is why the Climate Change Committee and the Committee on Civil Aviation Security are not expected to demand expert knowledge, but rather information about domestic sectoral interests. In the case of Denmark, national sectoral organisations such as the Lime and Brick Association and Danish Energy were able to provide the requested access goods and were thus given access to the comitology procedure in the form of bilateral meetings with the Danish Ministry of Climate and Energy, which represented Denmark in the Climate Change Committee. 
The national general organisation, the Confederation of Danish Industries, however, also gained access to the Ministry of Climate and Energy, despite our expectation that it would not be able to provide the demanded access goods, but rather 'information about domestic encompassing (general) interest'. It obtained access partly through a network, which the Ministry and the Confederation created jointly under the name 'Quota Network' and which still exists today. Through the network, members of the Confederation who had a special interest in climate matters would receive a status on current climate negotiations and would be able to ask questions and comment on the Ministry of Climate and Energy's policies, thereby giving the network members an insight into the current negotiation situation as well as give the Ministry an insight into industry concerns. In particular, the EU Emission Trading System and the related benchmark exercise were debated by the network, but the international climate developments within the realm of the UN were also in focus. In addition, the Ministry held a series of bilateral meetings with the Confederation concerning primarily one particular case which the Confederation raised on behalf of a member operating in a particularly vulnerable sector (Informant K).

The access of the Confederation of Danish Industries to the comitology procedure through the Danish Ministry of Climate and Energy can be seen in the light of two factors: firstly, the Confederation is the largest general business organisation in Denmark and a significant player on the Danish scene. It was therefore in constant contact with the Ministry of Climate and Energy regarding other cases, which may have created the basis for access in the case of $\mathrm{CO}_{2}$ quotas (Informant K). Another factor which may have eased access comprises the efforts made by the Confederation on the aforementioned single issue, where the Confederation could offer information about how the Commission's proposal would affect a single sector, which is a subset of what Bouwen denotes 'information about the encompassing (sectoral) national interest'. This allowed the Confederation to offer the access goods which both the Danish Ministry and the Committee on Climate Change demanded.

In the case of aviation safety, the Danish Civil Aviation Administration was the Danish national representative in the Committee on Civil Aviation Security. The Civil Aviation Administration was in contact with the sectoral organisation, Danish Airports Association (DANSAM), and a few airports that are not members of this organisation, because they could provide information on technical details on individual Danish airports (Informant H). The Civil Aviation Administration did not, however, contact for example the Confederation of Danish Industries, which acts as a sectoral organisation for various parts of the transport industry such as air transport, freight and public transport. This is because 'information about the encompassing (general) national interest', such as information that the business organisations did not want regulation or that regulation would increase its members' costs, is difficult to translate into detailed negotiations on the proposal in a comitology committee, and is therefore of little value for the members of a comitology committee. This organisation thus had too broad a scope to be able to provide the demanded access 
goods, and therefore did not obtain access to the comitology procedure (Informant $\mathrm{H}$ ).

In contrast to the case of $\mathrm{CO}_{2}$ quotas, there were contacts between BIAs and the European Parliament in the case of aviation safety. The Parliament (particularly the TRAN Committee) sought information on the implications of body scanners in airports and airlines, respectively, in order to assess whether there were grounds for objecting to the Commission's draft implementing measure (Informant A). Again, the European sectoral organisations such as ACI Europe and AEA were able to provide the requested access goods. This paved the way for access.

In sum, our findings show that a number of sectoral and general business interests were actively trying to obtain access to the comitology system in both our cases. Furthermore, BIAs appear to be active at both the European and the national arenas. As expected by our hypotheses based on Bouwen's (2004) access model, both sectoral and general business interests sought access through multiple channels, including the Commission, the national representatives in the comitology committees and the European Parliament. However, in the case of $\mathrm{CO}_{2}$ quotas, their interest in the European Parliament was smaller than we expected due to the nature of the Parliament's power in the comitology procedure. BIAs were generally successful in obtaining access, though to varying degrees. As expected by our hypotheses, the institutions in the comitology system were mostly interested in contacts with sectoral interests since they could offer the access goods in demand, in particular expert knowledge. General interests were not, however, completely shut out, but contacts were less intense.

\section{Conclusion and Lessons of the Case Studies for the Post-Lisbon Comitology System}

Our study of two comitology cases $-\mathrm{CO}_{2}$ quotas and aviation safety found clear traces of lobbying by BIAs. Lobbying efforts were targeted at the Commission, the member states in the comitology committees and the European Parliament. The efforts were successful in the sense that the BIAs were granted access.

Before drawing final conclusions from these findings, the most likely nature of our cases should be borne in mind. We deliberately selected cases that had important effects for outside interests, and we focused on the only comitology procedure that grants the European Parliament considerable influence. Our empirical setting thus made it likely that lobbying would take place and would be directed towards a range of EU actors. In light of the limited evidence on the subject, we believe this research design is justified. Our intention was to conduct a plausibility probe and investigate whether lobbying in the comitology system merits more systematic study in the future. We think that our plausibility probe paid off. Lobbying turned out to be prevalent and the phenomenon therefore deserves closer attention from social scientists in the future.

Furthermore, the analysis has pointed to characteristics that distinguish lobbying in the comitology system from normal lobbying activities in EU executive decision-making. First, the comitology procedures provide more 
access points for outside interests. They can not only target the Commission, but also the member states and the European Parliament. Second, compared to lobbying in the context of executive decision-making, lobbying in the comitology system appears to be dominated by sectoral organisations. This is due to the technical issues handled by the committees and the derived need for expert knowledge.

However, the question remains as to whether our cases are too likely, or too extreme, to be of general interest. First, is it extreme or unusual that comitology cases have important effects for BIAs? We do not think so. Comitology procedures are used in all EU policy areas, but are especially frequent within the environmental areas, the internal market and agriculture (Commission 2010a, Table 1). These are all areas where EU regulation is important to business interests.

Second, is the comitology procedure which we studied - the regulatory procedure with scrutiny - still relevant after the Lisbon Treaty, which entails the gradual phasing out of this specific procedure (cf. Hardacre and Kaeding 2011)? Since the post-Lisbon comitology system only comprises the advisory procedure and revised versions of the management and regulatory procedures (cf. Brandsma and Blom-Hansen 2012), the European Parliament now appears to play a more limited role in regards to the adoption of implementing acts. The introduction of delegated acts, however, foresees a considerable scrutiny role for the European Parliament, while comitology committees are the ones which lack formal scrutiny power.

Nonetheless, we believe that there are two reasons why our cases remain interesting in the post-Lisbon period. First, when preparing delegated acts, the Commission has agreed to consult expert groups of member state representatives. The exact status of this requirement will only become evident from practical use. Speculation by informed observers, however, is that this may amount to an informal comitology system (Peers and Costa 2012, 453). This suggests that comitology committees will continue to be interesting targets for lobbying in both the case of implementing and delegated acts. Moreover, the European Parliament has been granted access to the aforementioned expert groups. This was obtained as part of the inter-institutional negotiations on the 2011 comitology reform (Brandsma and Blom-Hansen 2012). This fact, combined with the European Parliament's considerable scrutiny role in relation to delegated acts, is likely to make the Parliament an attractive lobbying target.

Second, the new comitology system in relation to implementing acts does not grant the European Parliament more influence than it enjoyed under the old advisory, management and regulatory procedures, i.e. the pre-2006 comitology system. The European Parliament therefore does not appear to be an especially attractive lobbying target for BIAs in the case of implementing acts. However, the new comitology regulation includes a review clause stipulating an evaluation in 2016 (European Parliament and Council 2011, Article 15). If history provides any guide, all EU institutions will use this as an occasion to fight for more control positions in the comitology system. The European Parliament in particular is likely to fight for a more privileged position and, again judging from previous reforms, it is likely to 
succeed. The history of comitology reforms is to a large extent the history of gradually increasing influence for the European Parliament (Bergström 2005, 313-5; Blom-Hansen 2011, 17-21). In short, it is by no means certain that the European Parliament continues to be an unattractive target for lobbying in the post-Lisbon comitology system.

In sum, lobbyism in the comitology system seems to be a political phenomenon deserving more scholarly interest. Our study was limited to BIAs. It did not include consumer or environmental interests. Furthermore, at the national level it was limited to one member state, Denmark. Finally, we studied access, rather than influence, by outside interests. Access may be a prerequisite for influence, but does not equate to it. In the final analysis, the interesting question concerns influence and the extent to which outside interests succeed in introducing bias into the comitology system. These points are obvious ones for future research to address.

\section{Notes}

1. See Blom-Hansen $(2011,24-5)$ for a detailed explanation of the various procedures and their development over time.

2. See Section 5 for more information on stakeholder meetings in the specific cases of $\mathrm{CO}_{2}$ quotas and aviation safety.

3. At the beginning of the term of the Barroso II Commission the file was transferred to DG Climate.

4. As of 2010 named DG Move.

\section{References}

Alfé, M., G.J. Brandsma, and T. Christiansen. 2009. The functioning of comitology committees in practice. In 21st century comitology. Implementing committees in the enlarged European Union, eds. T. Christiansen, J.M. Oettel, and B. Vaccari, 133-51. Maastricht: European Institute of Public Administration.

Bergström, C.F. 2005. Comitology. Delegation of powers in the European Union and the committee system. Oxford: Oxford University Press.

Blom-Hansen, J. 2011. The EU comitology system in theory and practice. Houndsmills: Palgrave.

Bouwen, P. 2004. Exchanging access goods for access: a comparative study of business lobbying in the European Union institutions. European Journal of Political Research 43: 337-69.

Brandsma, G.J. 2010. Backstage Europe: comitology, accountability and democracy in the European Union. Utrecht: Utrecht University.

Brandsma, G.J., and J. Blom-Hansen. 2010. The EU comitology system: what role for the commission? Public Administration 88: 496-512.

Brandsma, G.J., and J. Blom-Hansen. 2012. Negotiating the post-Lisbon comitology system: institutional battles over delegated decision-making. JCMS: Journal of Common Market Studies 50: 939-57.

Chalmers, A.W. 2011. Interests, influence and information: comparing the influence of interest groups in the European Union. Journal of European Integration 33: 471-86.

Christiansen, T., and M. Dobbels. 2013. Delegated powers and inter-institutional relations in the EU after Lisbon: a normative assessment. West European Politics 36: 1159-77.

Christiansen, T., J.M. Oettel, and B. Vaccari, eds. 2009. 21st century comitology. Implementing committees in the enlarged European Union, 175-203. Maastricht: European Institute of Public Administration.

Coen, D. 2007. Empirical and theoretical studies in EU lobbying. Journal of European Public Policy 14: 333-45.

Commission. 2002. Governance by committee, the role of committees in European policy-making and policy implementation. Bruxelles: DG Forskning, EUR21705. 


\section{R.W. Nørgaard et al.}

Commission. 2009a. Commission Regulation No. 272/2009 of 2 April 2009 supplementing the common basic standards on civil aviation security laid down in the Annex to Regulation (EC) No. 300/2008 of the European Parliament and of the Council.

Commission. 2009b. Dossier CMTD(2009)0523, http://ec.europa.eu/transparency/regcomitology/ index.cfm?do=search.documentdetail\&t9sTtBEGv9U0G2Gbvwf0EDHDtxIWE3TWc5eFOWtUFL xsgRhLJX/HPj4gwIuGyS1X (accessed 26 March 2012).

Commission. 2009c. Stakeholder meeting of the European Climate Change Program (ECCP) Working Group on Emissions Trading on Benchmarks, Brussels, 6 November 2009, http://ec.europa.eu/ clima/documentation/ets/benchmarking_en.htm (accessed 11 August 2011).

Commission. $2009 \mathrm{~d}$. Communication from the Commission to the European Parliament and the Council - implementation of Article 290 of the Treaty on the Functioning of the European Union, Bruxelles, 9 December 2009, COM(2009)673.

Commission. 2010a. Report from the Commission on the working of committees during 2009, COM (2010)354 final.

Commission. 2010b. Dossier CMTD(2010)1356, http://ec.europa.eu/transparency/regcomitology/ index.cfm?do=search.documentdetail\&SbyYQSk9tOTHC58e7gg3ZC+rZ+ueyx0Zqi1wVw04RFhx bx1TISJ2Mfg5DtxY23N (accessed 26 March 2012).

Commission. 2011. Commission decision of 27 April 2011 determining transitional union-wide rules for harmonised free allocation of emission allowances pursuant to Article 10a of Directive 2003/ 87/EC of the European Parliament and of the Council.

Council of Ministers. 2006. Council decision of 28 June 1999 laying down the procedures for the exercise of implementing powers conferred on the Commission. Decision as amended by Decision 2006/512/EC, OJ L 200, 22 July 2006. Consolidated version, OJ C 255/4, 21 October 2006.

Daemen, H.H.F.M., and M.P.C.M. van Schendelen. 1998. The advisory committee on safety, hygiene and health protection at work. In EU Committees as influential policymakers, ed. M.P.C.M. van Schendelen, 129-48. Aldershot: Ashgate.

Dür, A. 2008. Interest groups in the European Union: how powerful are they? West European Politics 31: 1212-30.

Dür, A., and D. De Bièvre. 2007. The question of interest group influence. Journal of Public Policy 27: $1-2$.

Egan, M., and D. Wolf. 1999. Regulatory oversight in Europe: the case of comitology. In EU Committees: social regulation, law and politics, eds. C. Joerges and E. Vos, 239-59. Oxford: Hart Publishing.

European Parliament and Council. 2003. Directive 2003/87/EC of the European Parliament and of the Council of 13 October 2003 establishing a scheme for greenhouse gas emission allowance trading within the community and amending Council Directive 96/61/EC (Text with EEA relevance).

European Parliament and Council. 2011. Regulation (EU) No. 182/2011 of the European Parliament and of the Council of 16 February 2011 laying down the rules and general principles concerning mechanisms for control by Member States of the Commission's exercise of implementing powers. OJ L55, 28 February 2011, 13-8.

Gatt, A. 2009. Comitology in the field of GMO authorisation: implications for legitimacy. In 21st century comitology. Implementing committees in the enlarged European Union, eds. T. Christiansen, J.M. Oettel, and B. Vaccari, 175-203. Maastricht: European Institute of Public Administration.

George, A.L., and A. Bennett. 2005. Case studies and theory development in the social sciences. Cambridge, MA: MIT Press.

Greenwood, J. 2007. Interest representation in the European Union. 2nd ed. Basingstoke: Palgrave Macmillan.

Hardacre, A., and M. Kaeding. 2011. Delegated and implementing acts - the new comitology. EIPA Essential Guide. European Institute of Public Administration.

Kohler-Koch, B. 1997. Organized interests in the EC and the European Parliament. European Integration Online Papers 1, No. 009.

Mazey, S., and J. Richardson. 2006. Interest groups and EU policy making: organizational logic and venue shopping. In European Union. Power and policy-making, ed. J. Richardson, 208-68. London: Routledge.

Ministry of Climate and Energy. 2010. Grundnotat: Komiteprocedure i Klimakomitéen [Basic note: the comitology of the commitee on climate], København, 3 November 2010, www.ft.dk/samling/ 20101/almdel/euu/bilag/71/913322.pdf (accessed 9 August 2011).

Nedergaard, P. 2009. Business and politics in the European Union. Copenhagen: Djoef Publ. 
Neyer, J. 1998. The standing committee of foodstuffs: arguing and bargaining in comitology. In EU Committees as influential policymakers, ed. M.P.C.M. van Schendelen, 148-64. Aldershot: Ashgate.

Peers, S., and M. Costa. 2012. Accountability for delegated and implementing acts after the Treaty of Lisbon. European Law Journal 18: 427-60.

Philip, A.B. 1998. The eco-label regulatory committee. In EU Committees as influential policymakers, ed. M.P.C.M. van Schendelen, 164-79. Aldershot: Ashgate.

Richardson, J. 2007. Organized interests in the European Union. In Handbook of European Union politics, eds. K.E. Jørgensen, M.A. Pollack, and B. Rosamond, 231-47. London: Sage.

Schaefer, G.F., and A. Türk. 2007. The role of implementing committees. In The role of committees in the policy-process of the European Union. Legislation, implementation and deliberation, eds. T. Christiansen and T. Larsson, 182-201. Cheltenham: Edward Elgar.

\section{Appendix}

\section{List of informants}

\begin{tabular}{|c|c|c|c|}
\hline Interviewee & Organisation & Position & $\begin{array}{l}\text { Interview } \\
\text { date }\end{array}$ \\
\hline A & $\begin{array}{l}\text { European Parliament, Environmental } \\
\text { Committee }\end{array}$ & Policy Officer & 18.04.2011 \\
\hline B & $\begin{array}{l}\text { DG Climate Policy; Unit B2, } \\
\text { Benchmarking }\end{array}$ & Head of Unit & 18.04.2011 \\
\hline $\mathrm{C}$ & Eurometaux & $\begin{array}{l}\text { Director, Energy and } \\
\text { Climate Change } \\
\text { Policy }\end{array}$ & 19.04.2011 \\
\hline $\mathrm{D}$ & BUSINESSEUROPE & $\begin{array}{l}\text { Director, Industrial } \\
\text { Affairs }\end{array}$ & 19.04 .2011 \\
\hline $\mathrm{E}$ & $\begin{array}{l}\text { Confederation of Danish Industries } \\
\text { (Energy and Climate Policy } \\
\text { Department) }\end{array}$ & Policy Officer & 09.05 .2011 \\
\hline $\mathrm{F}$ & $\begin{array}{l}\text { European Parliament, Transportation } \\
\text { Committee }\end{array}$ & Policy Officer & 02.05 .2011 \\
\hline G & ACI Europe & $\begin{array}{l}\text { Senior Manager, } \\
\text { Aviation Security }\end{array}$ & 05.05 .2011 \\
\hline $\mathrm{H}$ & $\begin{array}{l}\text { Ministry of Transportation of } \\
\text { Denmark (Department for EU } \\
\text { Coordination, Air Transportation and } \\
\text { Security) }\end{array}$ & Head of Division & 27.05 .2011 \\
\hline I & $\begin{array}{l}\text { Confederation of Danish Industries } \\
\text { (Transportation Department) }\end{array}$ & Director & 23.05.2011 \\
\hline $\mathrm{J}$ & $\begin{array}{l}\text { DG Transport, Unit E5 Aviation } \\
\text { Security }\end{array}$ & Policy Officer & $\begin{array}{l}06.05 .2011 / \\
17.05 .2011\end{array}$ \\
\hline $\mathrm{K}$ & $\begin{array}{l}\text { Ministry of Climate and Energy of } \\
\text { Denmark (Danish Energy Agency) }\end{array}$ & $\begin{array}{l}\text { Civil Engineer, } \\
\text { Department of Energy } \\
\text { Supply }\end{array}$ & 26.05 .2011 \\
\hline
\end{tabular}

